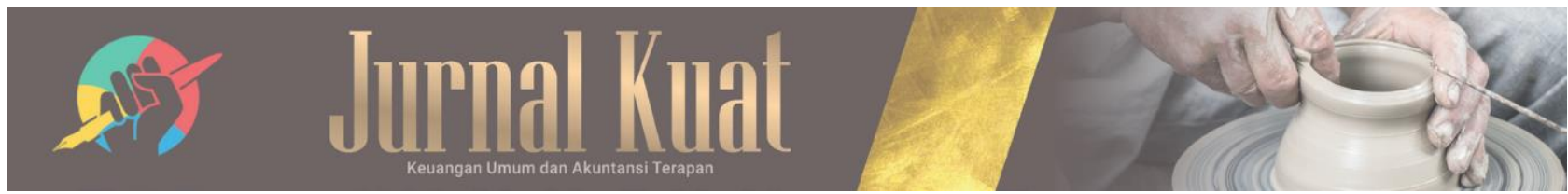

\section{ANALISIS PROMOSI DAN BRANDING UNTUK PENGUATAN EKSISTENSI KAMPUNG WAYANG KEPUHSARI, MANYARAN}

Mulyadi ${ }^{1}$

1) Universitas Sebelas Maret

Email : mulyadi_fe@staff.uns.ac.id

\begin{abstract}
Abstraksi
Upaya pemasaran online dan branding sudah dilakukan oleh pengrajin wayang di Kepuhsari Manyaran Wonogiri. Hanya saja upaya tersebut belum mampu meningkatkan penjualan produk seni wayang. Kunjungan ke Kampung Kepuhsari yang juga sudah dideklarasikan sebagai sebuah desa wisata juga tidak begitu banyak. Kegiatan pengabdian ini di samping untuk memberikan pelatihan penggunaan media sosial untuk kepentingan pemasaran online juga dimaksudkan untuk mengidentifikasi strategi pemasaran dan branding yang sudah dilakukan selama ini. Analisis SWOT digunakan untuk mencermati situasi dan kondisi yang ada sebelum kemudian diputuskan untuk diambil langkah lebih lanjut. Pemberian pelatihan pemasaran online dan branding dengan pendekatan teori dan praktik dilaksanakan dengan dipadukan dengan FGD. Hasil pengabdian yang penting yakni bahwa upaya pemasaran dan branding yang sudah dilakukan selama ini bersifat sporadis dan banyak mengalami kendala. FGD yang dilakukan menghasilkan analisis SWOT yang menunjukkan posisi kerajinan ukir wayang di Kepuhsari berada di kuadran 3, yang berarti bahwa untuk eksistensi pengrajin wayang Kepuhsari perlu melakukan perubahan strategi pemasaran dan branding.
\end{abstract}

Kata kunci: Analisis SWOT, Eksistensi, Pemasaran ukir wayang kulit

\begin{abstract}
Online marketing and branding efforts have been made by Wayang craftsmen in Kepuhsari, Manyaran Wonogiri. Unfortunately, these efforts have not been able to increase sales of puppet art products. There are only few tourist visits to Kepuhsari, which has also been declared a tourist village by the local government. This activity provide training in the use of social media for online marketing purposes. It is also intended to identify marketing and branding strategies that have been carried out so far. The SWOT analysis is used to examine pre-existing situations and conditions, and then is used to take further steps. This program provide online marketing training and branding with theoretical and practical approaches which is carried out in combination with FGDs. The important result is that marketing and branding efforts that have been made so far are sporadic and have many problems. SWOT analysis showed that the position of the puppet carving craft in Kepuhsari was in quadrant 3. This means that craftsmen need to change their marketing and development strategies so that their existence can be maintained.
\end{abstract}

Keywords: SWOT Analysis, Existence, Puppets

\section{PENDAHULUAN}

Kesenian wayang sudah berkembang di Nusantara dan Pulau Jawa pada khususnya sebelum keyakinan agama Hindu banyak dianut. Beberapa ahli berbeda pendapat mengenai sejarah lahirnya kesenian wayang ini. Ada ahli sejarah yang menyebutkan bahwa kesenian wayang yang asli Indonesia ini lahir pada kisaran tahun 900-an masehi. Ada juga ahli yang menyatakan bahwa kesenian ini lahir pada zaman neolithikum, yakni 1500 tahun sebelum masehi. Jika dilihat hingga kini, maka kesenian wayang ini sudah berusia lebih dari setengah milenium (hampir seribu tahun) (Basuki, 2006).

Usia kesenian yang hampir seribu tahun ini dihadapkan pada persoalan eksistensi. Pergantian generasi sebanyak 5 - 7 tingkat tentu ada pengaruhnya terhadap minat terhadap wayang itu sendiri. Jenis kesenian wayang yang pada awal mulanya berjumlah ratusan, kini tinggal puluhan saja yang masih bisa bertahan (Kusbiyanto, 2015) (Putro, 2015). Tentu banyak aspek yang menyebabkan semakin berkurangnya minat terhadap kesenian wayang ini, yang bisa diamati dari faktor internal kesenian wayang maupun dari faktor eksternal. 
Faktor internal yang dimaksud misalnya semakin berkurangnya jumlah pengrajin yang masih menekuni profesi ini. Kesenian wayang tidak banyak dikembangkan (data pengrajin wayang nasional). Jumlah pengrajin wayang semakin berkurang dari waktu ke waktu (Lantiva, 2019).

Faktor ekonomi berupa penghasilan yang tidak menentu diduga menjadi penyebab utama semakin berkurangnya jumlah pengrajin wayang tersebut. Sebagai contohnya pada tahun 2015, standar kebutuhan hidup rata-rata Kabupaten Wonogiri sebesar Rp. 1.101.000,- per bulan (BPS, 2018). Namun, demikian penghasilan pengrajin wayang hanya berkisar Rp. 375.000,- per bulan (Pujiastuti, Rahmawati, Riani; 2015).

Faktor eksternal yang menyebabkan semakin pudarnya minat terhadap wayang adalah karena adanya tekanan ekonomi global. Ini berdampak pada banyaknya peralihan profesi penduduk desa, tertutama di kalangan pemudanya. Pemuda cenderung merantau setelah menamatkan pendidikannya. Termasuk di lingkungan para pengrajin wayang (Lantiva, 2019).

Penurunan jumlah pengrajin wayang juga terjadi di Jawa Tengah, khususnya daerah sekitar Surakarta yang menjadi basis dari tumbuh dan berkembangnya kesenian wayang. Pusat pengrajin wayang di daerah Surakarta dan sekitarnya adalah sebagai berikut:

Tabel 1 Sentra Kerajinan Wayang

\begin{tabular}{clllc}
\hline \hline No & Desa & Kecamatan & Kab/Kodia & Unit Usaha \\
\hline 1 & Sonorejo & Sukoharjo & Kab. Sukoharjo & 20 \\
2 & Punduhsari & Manyaran & Kab. Wonogiri & 9 \\
3 & Sidowarno & Wonosari & Kab. Klaten & 18 \\
4 & Sumber & Dukun & Kab. Magelang & 20 \\
\hline
\end{tabular}

Sumber: Data Departemen Perindustrian dan Perdagangan Jateng, 2012

Faktor internal dan eksternal yang disebutkan di atas tentu mengancam kelangsungan hidup dari kesenian wayang asli Indonesia ini sebagai sebuah warisan budaya (heritage). Berkenaan dengan fakta ini maka diperlukan serangkaian upaya untuk tetap mempertahankan eksistensi kesenian wayang. Kampanye dan promosi mutlak dibutuhkan agar para pemuda khususnya dapat menerima kesenian ini, mengingat segmen penggemar kesenian wayang ini berada di rentang usia 50 tahun (Putro, 2015).

Terbatasnya konsumen wayang dapat disikapi dengan masif melalui upaya promosi produk wayang. Maksudnya, konsumen kerajinan wayang dapat bertambah jika dibarengi dengan promosi dan pemasaran yang terus menerus. Promosi dalam hal ini dapat memanfaatkan kekuatan pemasaran online yang berkembang pesat saat ini. Terdapat perbedaan penggunaan media pemasaran online oleh pengrajin untuk mempromosikan wayang ini.
Media yang paling banyak digunakan untuk promosi penjualan wayang adalah marketplace di Facebook. Beragam kerajinan wayang ditawarkan melalui marketplace facebook, mulai dari wayang kualitas rendah sampai dengan wayang kualitas baik. Sementara instagram banyak dipilih pelaku kesenian wayang untuk mengkampanyekan aktivitas seputar pewayangan, dalam hal ini misalnya aktivitas tokoh wayang, pentas pewayangan, peristiwa pewayangan, dll. Berikut adalah beberapa dokumentasi penggunaan marketplace dan instagram dalam kaitannya dengan perwayangan:
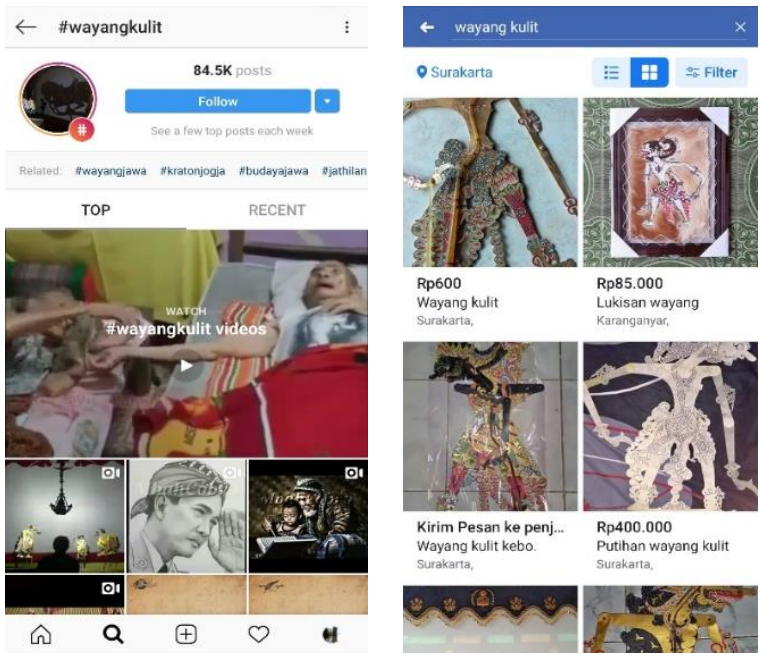

\section{Gambar 1. Perbedaan penggunaan marketplace untuk promosi wayang \\ (Sumber: instagram.com dan facebook.com)}

Setidaknya contoh keterkaitan promosi kerajinan wayang yang berkaitan dengan penjualan ini terjadi di Sentra Kerajinan Wayang Kepuhsari, Manyaran, Wonogiri. Beberapa upaya promosi dan pencitraan (branding) yang sudah dilakukan oleh pengrajin wayang di Kepuhsari yakni:

1. Masyarakat secara swadaya berkelompok dan mendirikan sanggar seni. Sanggar ini digunakan untuk kegiatan pelatihan pembuatan wayang sekaligus show room sederhana untuk promosi (Data Primer, 2018).

2. Pengunjung Kepuhsari selain dapat membeli kerajinan wayang juga bisa mendapatkan ilmu tentang proses pembuatan wayang. Pengrajin bersedia menunjukkan teknis membuat wayang di sanggar tersebut (Data Primer, 2018).

3. Masing-masing pengrajin juga sudah mulai melakukan promosi dan branding melalui media sosial.

4. Pengrajin wayang Kepuhsari juga sudah bekerja sama dengan PO Bis dengan trayek luar kota (Jakarta, Bandung, dll) dalam memasarkan kerajinan wayangnya. PO Bis diminta mengenalkan dan menginformasikan kepada 
penumpang bahwa ada kampung di Wonogiri yang memproduksi wayang.

5. Bekerjasama dengan agen perjalanan wisata untuk mengarahkan dan membuat paket wisata yang salah satu objeknya adalah desa Kepuhsari penghasil wayang.

Pengrajin juga bekerjasama dengan pihak sekolah setingkat dasar dan menengah untuk membuat kunjungan ke Kepuhsari.

Hanya saja saat ini semua upaya tersebut belum cukup untuk meningkatkan volume penjualan kerajinan wayang di Kepuhsari. Omset penjualan rata-rata pengrajin wayang di Kepuhsari cenderung mengalami penurunan dari tahun ke tahun. Berikut adalah data omset pengrajin wayang di Kepuhsari:

Tabel 2. Perhitungan Pendapatan Pengrajin Wayang Kepuhsari/ tahun

\begin{tabular}{|c|c|c|c|c|}
\hline $\begin{array}{l}\text { Tah } \\
\text { un }\end{array}$ & $\begin{array}{c}\text { Jumlah } \\
\text { Pengra } \\
\text { jin }\end{array}$ & $\begin{array}{l}\text { Omset } \\
\text { Total }\end{array}$ & $\begin{array}{l}\text { Rata- } \\
\text { rata }\end{array}$ & $\begin{array}{l}\text { Per } \\
\text { bulan }\end{array}$ \\
\hline 1980 & 45 & $\begin{array}{c}300.000 \\
000\end{array}$ & $\begin{array}{c}6.666 .6 \\
67\end{array}$ & $\begin{array}{c}555.5 \\
56\end{array}$ \\
\hline 1983 & 55 & $\begin{array}{c}360.000 \\
000\end{array}$ & $\begin{array}{c}6.545 .4 \\
55\end{array}$ & $\begin{array}{c}545.4 \\
55\end{array}$ \\
\hline 2015 & 100 & $\begin{array}{c}450.000 \\
000\end{array}$ & $\begin{array}{c}4.500 .0 \\
00\end{array}$ & $\begin{array}{c}375.0 \\
00\end{array}$ \\
\hline
\end{tabular}

Sumber: Pujiastuti, Rahmawati, Riani (2015)

Banyak faktor tentunya dapat dianalisis untuk diambil kesimpulan penyebab dari semakin berkurangnya minat terhadap wayang kulit yang berdampak pada turunnya pendapatan pengrajin. Disamping faktor belum berhasilnya upaya promosi yang disebutkan di awal, masih terdapat beberapa fenomena lain, misalnya:

1) Industri kerajinan wayang Kepuhsari seakan berdiri terpisah dari kekayaan alam yang dimiliki oleh Kepuhsari dan Manyaran pada umumnya. Daerah ini sebenarnya memiliki beberapa potensi wisata alam yang dapat dijual dan dikembangkan sebagai sebuah paket wisata dengan suvernir berupa wayang kulit. Objek tersebut seperti: air terjun banyu nibo, gunung kotak, dan gunung batu. Hanya saja semua potensi tersebut belum ada yang dipotimalkan untuk menjadi sebuah objek wisata.

2) Berkembangnya wisata artifisial di sekitar Wonogiri (Kepuhsari). Saat ini banyak wisata buatan (artifisial) yang cukup berhasil menarik minat para pengunjung, misalnya saja di Jogjakarta ada Taman Pelangi, Upside Down World, Kalibiru, dan Tebing Breksi. Kemudian di Surakarta terdapat Pandawa Water World, Transformer Park, dan De Tjolomadoe. Karanganyar memiliki Wisata Bukit Sekipan, Sondokoro, dan Aerospace Edupark. Boyolali mempunyai Patung Sapi Boyolali, Taman Air Tlatar, Lembah Gunung Madu dan Omah Bambu Merapi.

3) Kecenderungan wisatawan (selfie) swafoto dalam benwisata juga menjadi faktor tersendiri. Perkembangan teknologi HP pintar (smartphone) semakin mendorong perubahan gaya hidup wisatawan. Banyak yang dalam berwisata tujuan utamanya adalah untuk mengabadikan peristiwa/ momen (Mulawarwan dan Nur safitri, 2017)

4) Mahalnya harga komoditas wayang yang asli (original) dari bahan kulit sapi. Sebagaimana diketahui untuk wayang dengan kualitas baik bisa dijual sampai jutaan rupiah. Harga ini tentu memiliki segmen tersendiri (Santoso, 2015).

Beberapa fakta tersebut di atas mendorong perlunya dilakukan evaluasi terhadap strategi promosi dan branding yang selama ini dilakukan oleh pengrajin wayang Kepuhsari. Proses evaluasi didahului dengan pemetaan dan identifikasi kondisi home industry Wayang di Kepuhsari. Kondisi yang dimaksud adalah dari aspek internal seni wayang kulit Kepuhsari (kekuatan dan kelemahan) dan dari aspek eksternal posisi seni wayang ini (peluang dan ancaman).

\section{RUMUSAN MASALAH}

Kampung Kepuhsari Manyaran telah dideklarasikan sebagai sebuah desa tujuan wisata dengan komoditas utamanya berupa seni wayang kulit. Seni yang dimaksud adalah produk wayang kulit dan industri pembuatan wayang kulitnya. Pendeklarasian ini dimaksudkan agar eksistensi desa sebagai salah satu cagar budaya dapat bertahan dan berkembang. Masyarakat di dorong untuk semakin produktif dalam hal memproduksi wayang kulit.

Namun demikian dalam ekonomi dikenal hukum supply creates its own demand sejauh ini tidak begitu sukses diterapkan di Kepuhsari. Upaya promosi yang beraneka ragam dan ekspansif (supply) belum mendapatkan hasil yang dikehendaki (demand). Jumlah pengunjung dan pembeli produk wayang kulit cenderung stagnan. Akibatnya kehidupan ekonomi dari pengrajin wayang juga tidak cukup terangkat dari menjalani profesi sebagai pengrajin. Kondisi demikian jika berlangsung terus menerus akan berpotensi pada semakin berkurangnya jumlah seniman wayang di Kepuhsari dan Indonesia pada umumnya.

\section{TUJUAN KEGIATAN}

Jumlah seni wayang yang terus semakin berkurang jumlah peminatnya akan berpengaruh kepada semua aktivitas yang terkait. Dalam hal ini misalnya produktivitas pengrajin wayang dan pentas pertunjukan wayang yang lambat laun akan semakin punah. Wayang sebagai sebuah kekayaan 
budaya bangsa (heritage) sudah semestinya harus dipertahankan.

Upaya mempertahankan kekayaan budaya ini dilaksanakan oleh tim dengan menyelenggarakan kegiatan pengabdian kepada masyarakat (PKM). Secara umum kegiatan pengabdian ini bertujuan untuk memetakan posisi kerajinan seni wayang di Kepuhsari Manyaran untuk digunakan sebagai evaluasi strategi pemasaran yang dilakukan selama ini. Ini penting dilakukan mengingat upaya pemasaran sudah dilakukan namun tidak kunjung memberikan hasil yang diharapkan.

Dengan terpetakannya posisi (kekuatan, kelemahan, peluang, dan ancaman) yang ada, dapat diketahui kesesuaianan strategi yang selama ini diterapkan. Sekaligus dapat diputuskan strategi terbaik yang dapat diterapkan di waktu yang akan datang.

\section{METODE PELAKSANAAN}

Kegiatan pengabdian ini dilaksanakan dengan 2 (dua) pendekatan. Pendekatan yang pertama yakni pemberian pelatihan mengenai strategi pemasaran yang modern, yakni: penggunaan media sosial untuk kepentingan pemasaran online dan pelatihan video grafis untuk branding melalui akun youtube.

Pelatihan ini dimaksudkan untuk membekali pengetahuan tentang penggunaan media sosial yang produktif. Walaupun sebenarnya pengrajin sudah mulai menggunakan media sosial yang dimiliki, namun sifatnya masih sporadis. Kunci-kunci pemasaran online belum dikuasai oleh pengrajin. Oleh karenanya kegiatan pelatihan ini sangat dibutuhkan dan akan membawa dampak yang positif.

Pendekatan kedua yang digunakan dalam kegiatan pengabdian ini adalah Focus Group Discussion (FGD). FGD diarahkan pada identifikasi faktor internal (kekuatan dan kelemahan) dan faktor eksternal (peluang dan ancaman) yang dapat dikembangkan atau diminimalisasi. Pengrajin dibagi menjadi beberapa kelompok kemudian berdiskusi dengan dipandu oleh tim pengabdian.

Setelah diperoleh hasil diskusi berupa pemetaan faktor internal dan eksternal, kemudian tim pengabdian melakukan analisis. Alat analisis yang dipakai adalah analisis SWOT. Alat ini akan menjadi sangat berguna ketika pada proses penentuan skala prioritas pengembangan, penghitungan bobot, dan penentuan peringkat dari masing-masing indikator dilakukan secara objektif.

Upaya untuk mendapatkan objektivitas dilakukan dengan: 1) memberikan pemahaman yang utuh kepada responden tentang butir-butir pertanyaan dalam kuesioner, 2) responden sepenuhnya diberikan kuasa untuk memberikan jawaban sesuai dengan persepsinya terhadap masalah yang dibahas. Dengan demikian diperoleh data yang cukup bervariasi atas permasalahan yang sama.
Objektivitas ini akan sangat menentukan hasil dari analisis SWOT yang dilakukan. Analisis SWOT dimulai dari identifikasi faktor internal dan eksternal. Proses identifikasi dilanjutkan dengan penentuan bobot yang juga secara objektif ditentukan oleh masingmasing responden. Prinsip nilai bobot ini yakni semakin besar maka indikator semakin diperhitungkan. Kemudian dalam penentuan skala prioritas menggunakan prinsip sebagai berikut:

1) Indikator yang positif (kekuatan dan pelvang) diberikan angka 1 untuk peringkat tertinggi, dan angka 4 untuk peringkat terendah.

2) Indikator yang negatif (kelemahan dan ancaman) diberikan angka 4 untuk peringkat tertinggi, dan angka 1 untuk peringkat terendah.

\section{HASIL DAN PEMBAHASAN}

Hasil yang penting untuk dibahas dari kegiatan pengabdian kepada msyarakat ini antara lain sebagai berikut:

1. Kegiatan pelatihan penggunaan media sosial, video grafis, dan youtube berjalan baik dengan diikuti oleh 20 orang pengrajin wayang di Kepuhsari.

Pemilihan 20 orang dari 50 orang keseluruhan pengrajin yang ada di Kepuhsari ini sepenuhnya oleh pengurus kelompok sadar wisata (Pokdarwis) yang ada di Kepuhsari dan menjadi mitra dalam kegiatan ini. Pengrajin yang diundang oleh Pokdarwis ini selanjutnya diprioritaskan untuk menjadi penggerak dari aktivitas pemasaran online dan branding atas produk wayang dan kerajinan yang ada di Kepuhsari.

Pengrajin yang diundang pada kegiatan pelatihan ini rata-rata dapat menyerap materi yang disampaikan. Terdapat beberapa yang pemahamannya tidak sempurna, dikarenakan pada saat melakukan simulasi yang bersangkutan mengalami persoalan dengan kekuatan sinyal internet. Kemampuan menyerap materi pemasaran online dan branding ini tidak lepas dari rentang usia peserta pelatihan yang rata-rata masih muda (30-45 tahun) dan melek dengan perkembangan teknologi informasi dan komunikasi.

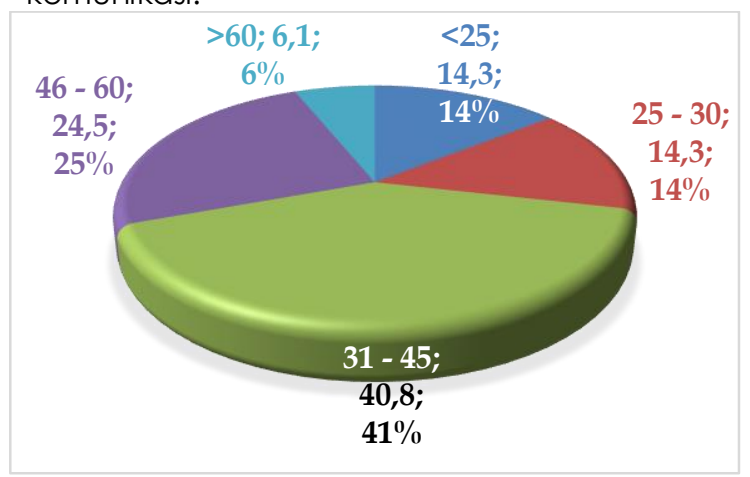

Gambar 2. Jumlah peserta pelatihan menurut usia 
Keterkaitan rentang usia dan daya serap peserta pelatihan tersebut sejalan dengan temuan dari survei yang dilakukan APJII (2017). Survei tentang perilaku dan penetrasi pengguna internet di Indonesia ini menyebutkan bahwa pengguna internet terbesar jumlahnya ada di rentang usia 1954 tahun. Rentang usia peserta pelatihan terdapat di kelompok usia tersebut.

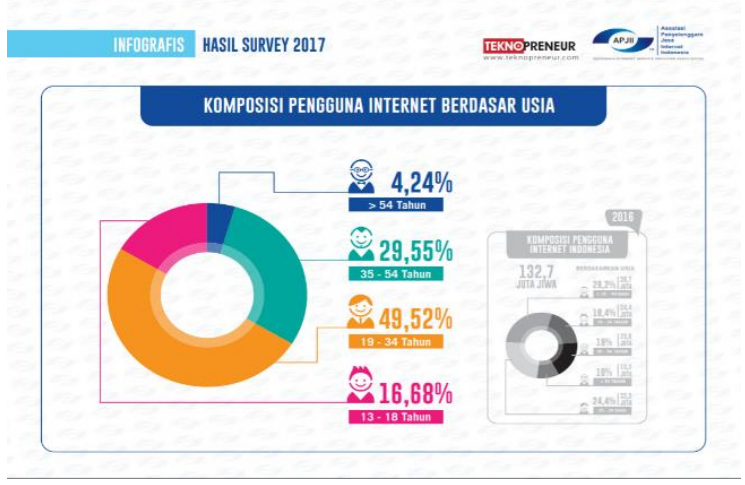

\section{Gambar 3. Komposisi pengguna internet di Indonesia menurut usia (Sumber: APJII, 2017)}

Pemahaman peserta pelatihan yang belum sempurna diantisipasi dengan pemberian materi yang dicetak sejumlah peserta yang hadir. Setiap peserta mendapatkan 1 bendel materi yang membahas secara detail teknis dan tahapan melakukan kegiatan pemasaran online. Dengan demikian meskipun pada saat menerima pelatihan ada peserta yang kurang dapat mengikuti, maka yang bersangkutan bisa mengulang kembali di rumah dengan kekuatan sinyal internet yang lebih bagus daripada sewaktu di lokasi pelatihan.

Disamping persoalan daya serap terhadap materi yang diberikan ini, satu hal lagi yang penting dibahas yakni terkait dengan pola pemasaran yang sejauh ini sudah dilakukan pengrajin wayang Kepuhsari. Terungkap fakta bahwa masing-masing pengrajin yang tergabung di dalam Pokdanwis ternyata belum terkoordinasi dengan baik soal pemasaran produknya. Masing-masing berjalan sesuai dengan kemampuan dan sumber daya yang dimilikinya. Peran Pokdanwis dalam mengkoordinir dan mengarahkan pemasaran dalam hal ini belum maksimal.

Teknik pemasaran yang digunakan pengrajin secara tidak disadari sudah mengarah kepada teknik-teknik yang dikenal dalam ilmu pemasaran. Contohnya sudah ada yang ketika posting di media sosial menggunakan keterangan/caption dengan konsep soft selling (penawaran yang halus) atau bahkan covert selling (terselubung). Namun, pada saat yang sama pengrajin tersebut tidak memperhatikan persoalan timing/periode posting. Padahal dalam menggunakan media sosial untuk kepentingan pemasaran online, persoalan periodisasi/timing sangat menentukan berhasil tidaknya sebuah promosi/kampanye.

Permasalahan berikutnya adalah penggunaan gambar yang seadanya. Kemampuan pengambilan foto produk dan perangkat yang seadanya menyebabkan seringkali gambar tidak cukup bagus. Padahal di dalam pemasaran menggunakan media sosial, aspek gambar juga sangat penting dan menentukan keberhasilan dari promosi yang dilakukan.

Pada akhirnya, kegiatan pengabdian ini memberikan tambahan pemahaman secara teoritis dan praktis kepada pengrajin untuk dapat melakukan pemasaran online. Pengrajin mendapatkan tambahan teori penjualan online, dan sekaligus melakukan simulasi praktik pemasaran online.

2. Pembahasan penting yang kedua adalah hasil FGD untuk mengevaluasi kinerja pemasaran dan branding yang sudah dilakukan.

FGD ini juga untuk mengidentifikasi langkah pemasaran selanjutnya. Proses identifikasi ini melibatkan pengrajin dalam jumlah yang lebih banyak daripada kegiatan pelatihannya. Jumlah pengrajin yang dihadirkan sebanyak $48(87,27 \%)$ dari jumlah keseluruhan pengrajin wayang sebanyak 55 di Kepuhsari. Pengrajin yang hadir kemudian dibagi ke dalam 8 kelompok untuk mengadakan diskusi terkait dengan perkembangan seni kerajinan wayang di Kepuhsari. Akhir dari diskusi kemudian masing-masing pengrajin mengisi kuesioner yang mengidentifikasi kelebihan, kekuatan, peluang, dan ancaman terhadap kelangsungan seni kerajinan ukir wayang di Kepuhsari.

Berikut adalah hasil identifikasi faktor internal dari seni kerajinan wayang Kepuhsari, Manyaran:

a) Faktor kekuatan (strenghts) terdiri dari beberapa indikator berikut: 1) kemampuan pengrajin yang mumpuni, 2) pengrajin wayang telah memiliki komunitas, 3) produk wayang yang bersifat unik dan spesial, 4) pasokan bahan baku yang lancar, 5) produk wayang memiliki harga jual yang tinggi, 6) fleksibilitas dalam jumlah pemesanan.

b) Faktor kelemahan (weakness) terdiri dari beberapa indikator berikut: 1) jumlah pengrajin seni wayang yang semakin terbatas, 2) proses pembuatan wayang yang membutuhkan waktu yang lama, 3) jaringan pemasaran yang tidak cukup banyak, 4) kendala komunikasi diantara pengrajin wayang yang ada, 5) pengrajin belum memiliki konsep pemasaran yang jelas, dan 6) penjualan yang tidak cukup bagus.

Kemudian untuk identifikasi faktor eksternal yang berdampak pada posisi seni kerajinan wayang di Kepuhsari adalah sebagai berikut:

a) Faktor peluang (opportunities) terdiri dari beberapa indikator berikut: 1) persaingan rendah dari produk sejenis, 2) didukung oleh wisata alam 
di sekitarnya, 3) dekat dengan central business district (CBD), 4) dukungan dari pemerintah untuk melestarikan produk, 5) penetapan desa wisata Kepuhsari sebagai Kampung Wayang, dan 6) berkembangnya media promosi online.

b) Faktor ancaman (threats) terdiri dari beberapa indikator sebagai berikut: 1) jumlah pengunjung tidak cukup banyak, 2) kebutuhan akan produk tidak banyak, 3) segmen pembeli produk sangat terbatas, 4) banyak kendala terhadap proses pemasaran, 5) berkembangnya wisata artifisial (buatan), 6) fasilitas publik yang mendukung belum dikembangkan, dan 7) tidak adanya transportasi umum yang menjangkau.

Analisis SWOT selanjutnya dilakukan penghitungan terhadap bobot. Nilai dari bobot ini dilakukan dengan menghitung angka rata-rata dari jawaban yang sudah diberikan oleh 48 orang responden. Kemudian dari angka rata-rata tersebut dijumlahkan untuk masing-masing faktor (internal dan eksternal). Kemudian penghitungan nilai bobot menggunakan rumus berikut:

$$
N \text { bobot }=\frac{\text { rata }- \text { rata indikator }}{\text { Total rata }- \text { rata }}
$$

Hasilnya pembobotan faktor-faktor internal sebagai berikut:

\section{Tabel 3. Bobot IFAS}

\begin{tabular}{|c|l|r|r|r|}
\hline No & KEKUATAN & Jumlah & Rata-rata & \multicolumn{1}{c|}{ Nilai } \\
\hline \hline 1 & Kemampuan pengrajin mumpuni & 161 & 3,354 & 0,097 \\
\hline 2 & Pengrajin telah memiliki komunitas & 134 & 2,792 & 0,081 \\
\hline 3 & Produknya wayang unik dan spesial & 108 & 2,250 & 0,065 \\
\hline 4 & Pasokan bahan baku lancar & 120 & 2,500 & 0,072 \\
\hline 5 & Produk wayang memiliki nilai jual tinggi & 131 & 2,729 & 0,079 \\
\hline 6 & Fleksibilitas dalam pesanan & 146 & 3,042 & 0,088 \\
\hline No & KELEMAHAN & 125 & 2,604 & 0,075 \\
\hline \hline 1 & Jumlah pengrajin terbatas & 136 & 2,833 & 0,082 \\
\hline 2 & Proses pembuatan wayang lama & 142 & 2,958 & 0,085 \\
\hline 3 & Jaringan pemasaran tidak banyak & 160 & 3,333 & 0,096 \\
\hline 4 & Kendala komunikasi dari pengrajin wayang & 145 & 3,021 & 0,087 \\
\hline 5 & Pengrajin tidak memiliki konsep pemasaran online & 155 & 3,229 & 0,093 \\
\hline 6 & Penjualan yang tidak cukup bagus & & 34,646 & 1,000 \\
\hline
\end{tabular}

Berdasarkan tabel di atas terlihat bahwa indikator kekuatan berupa kemampuan pengrajin yang mumpuni memiliki nilai bobot yang hampir sama dengan indikator kelemahan berupa kendala komunikasi diantara pengrajin. Namun secara keseluruhan bobot untuk faktor kelemahan lebih besar daripada kekuatan.

Kemudian hasil dari pembobotan faktor-faktor eksternal adalah sebagai berikut:

\section{Tabel 4. Bobot EFAS}

\begin{tabular}{|c|c|c|c|c|}
\hline No & PELUANG & Jumlah & Rerata & Nilai \\
\hline 1 & Persaingan rendah dari produk sejenis & 112 & 2,333 & 0,068 \\
\hline 2 & Didukung oleh wisata alam di sekitarnya & 147 & 3,063 & 0,089 \\
\hline 3 & Dekat dengan central business district & 138 & 2,875 & 0,084 \\
\hline 4 & Dukungan dari pemerintah untuk melestarikan produk & 136 & 2,833 & 0,082 \\
\hline 5 & Penetapan desa wisata Kepuhsari sebagai Kampung Wayang & 151 & 3,146 & 0,091 \\
\hline 6 & Berkembangnya media promosi online & 158 & 3,292 & 0,096 \\
\hline No & ANCAMAN & & & \\
\hline 1 & Jumlah pengunjung tidak cukup banyak & 132 & 2,750 & 0,080 \\
\hline 2 & Kebutuhan akan produk tidak banyak & 157 & 3,271 & 0,095 \\
\hline 3 & Segmen pembeli produk sangat terbatas & 155 & 3,229 & 0,094 \\
\hline 4 & Banyak kendala terhadap proses pemasaran & 112 & 2,333 & 0,068 \\
\hline 5 & Berkembangnya wisata artifisial (buatan) & 149 & 3,104 & 0,090 \\
\hline \multirow[t]{2}{*}{6} & Fasilitas publik yang mendukung belum dikembangkan & 105 & 2,188 & 0,064 \\
\hline & & & 34,417 & 1,000 \\
\hline
\end{tabular}

Nilai bobot untuk indikator peluang berupa berkembangnya media promosi online memiliki nilai yang hampir sama dengan 3 indikator kelemahan yaitu: kebutuhan produk yang tidak banyak, segmen pembeli yang terbatas, dan tidak adanya transportasi umum yang menjangkau Kepuhsari. Secara keseluruhan, terlihat bahwa secara keseluruhan nilai bobot untuk peluang lebih besar daripada ancaman.

Langkah berikutnya dalam analisis SWOT adalah dengan menentukan pemeringkatan masingmasing indikator untuk strategi pengembangan. Sebagaimana disebutkan di awal bahwa untuk faktor yang memiliki nilai positif (kekuatan dan pelvang) nilai prioritasnya adalah 4. Sedangkan untuk faktor negatif (kelemahan dan ancaman) yang menjadi prioritas peringkat adalah yang bernilai 1. Hasilnya pemerinkatan faktor internal (IFAS) adalah sebagai berikut:

\section{Tabel 5. Peringkat IFAS}

\begin{tabular}{|r|l|c|c|}
\hline No & \multicolumn{1}{|c}{ KEKUATAN } & Jumlah & Nilai \\
\hline \hline 1 & Kemampuan pengrajin mumpuni & 77 & 1,60 \\
\hline 2 & Pengrajin telah memimiliki komunitas & 90 & 1,88 \\
\hline 3 & Produknya wayang unik dan spesial & 165 & 3,44 \\
\hline 4 & Pasokan bahan baku lancar & 127 & 2,65 \\
\hline 5 & Produk wayang memiliki nilai jual tinggi & 161 & 3,35 \\
\hline 6 & Fleksibilitas dalam pesanan & 98 & 2,04 \\
\hline No & KELEMAHAN & Jumlah & Nilai \\
\hline \hline 1 & Jumlah pengrajin terbatas & 157 & 3,27 \\
\hline 2 & Proses pembuatan wayang lama & 164 & 3,42 \\
\hline 3 & Jaringan pemasaran tidak banyak & 149 & 3,10 \\
\hline 4 & Kendala komunikasi dari pengrajin wayang & 104 & 2,17 \\
\hline 5 & Pengrajin tidak memiliki konsep pemasaran online & 107 & 2,23 \\
\hline 6 & Penjualan yang tidak cukup bagus & 90 & 1,88 \\
\hline
\end{tabular}

Berdasarkan nilai pemeringkatan maka pengembangan fokus pada pemanfaatan karakter wayang yang unik dan spesial $(3,44)$ untuk meminimalisir penjualan yang tidak cukup bagus $(1,88)$. Kemudian hasil dari pemeringkatan faktor eksternal (EFAS) adalah sebagai berikut: 


\section{Tabel 6. Peringkat EFAS}

\begin{tabular}{|c|l|c|c|}
\hline No & \multicolumn{1}{|c|}{ PELUANG } & Jumlah & Rerata \\
\hline \hline 1 & Persaingan rendah dari produk sejenis & 93 & 1,94 \\
\hline 2 & Didukung oleh wisata alam di sekitarnya & 148 & 3,08 \\
\hline 3 & Dekat dengan central business district & 116 & 2,42 \\
\hline 4 & Dukungan dari pemerintah untuk melestarikan produk & 160 & 3,33 \\
\hline 5 & Penetapan desa wisata Kepuhsari sebagai Kampung Wayang & 153 & 3,19 \\
\hline 6 & Berkembangnya media promosi online & 130 & 2,71 \\
\hline No & ANCAMAN & Jumlah & Rerata \\
\hline 1 & Jumlah pengunjung tidak cukup banyak & 116 & 2,42 \\
\hline 2 & Kebutuhan akan produk tidak banyak & 156 & 3,25 \\
\hline 3 & Segmen pembeli produk sangat terbatas & 132 & 2,75 \\
\hline 4 & Banyak kendala terhadap proses pemasaran & 93 & 1,94 \\
\hline 5 & Berkembangnya wisata artifisial (buatan) & 152 & 3,17 \\
\hline 6 & Fasilitas publik yang mendukung belum dikembangkan & 89 & 1,85 \\
\hline
\end{tabular}

Berdasarkan nilai pemeringkatan tersebut maka pengembangan fokus pada pemanfaatan dukungan dari pemerintah $(3,33)$ untuk pengembangan fasilitas publik yang belum mencukupi di Kepuhsari $(1,85)$. Dukungan dalam hal ini terutama bagi pemerintah desa dan Kabupaten Wonogiri untuk menyediakan akses yang memadai dan fasilitas publik yang mencukupi.

Langkah berikutnya dalam analisis SWOT adalah dengan menghitung selisih antara faktor internal dan eksternal. Selisih antara faktor internal (kekuatan dikurangi kelemahan) akan membentuk sumbu $X$, dan selisih faktor eksternal (peluang dikurangi dengan ancaman) akan membentuk sumbu Y. Kemudian kedua sumbu disilangkan untuk menentukan posisi seni kerajinan wayang Kepuhsari di kuadran SWOT. Nilai $X$ diperoleh dari menjumlahkan bobot indikator setelah dikalikan peringkatnya. Hasilnya perhitungan nilai $X$ adalah sebagai berikut:

\section{Tabel 7. Perhitungan Nilai $X$}

\begin{tabular}{|c|c|c|c|c|}
\hline No & KEKUATAN & ВОВОт & PERINGKAT & BOBOT $x$ PERINGKAT \\
\hline 1 & Kemampuan pengrajin mumpuni & 0,097 & 1,604 & 0,155 \\
\hline 2 & Pengrajin telah memimiliki komunitas & 0,081 & 1,875 & 0,151 \\
\hline 3 & Produknya wayang unik dan spesial & 0,065 & 3,438 & 0,223 \\
\hline 4 & Pasokan bahan baku lancar & 0,072 & 2,646 & 0,191 \\
\hline 5 & Produk wayang memiliki nilai jual tinggi & 0,079 & 3,354 & 0,264 \\
\hline \multirow[t]{2}{*}{6} & Fleksibilitas dalam pesanan & 0,088 & 2,042 & 0,179 \\
\hline & & 0,481 & & 1,164 \\
\hline No & KELEMAHAN & Вовот & PERINGKAT & \\
\hline 1 & Jumlah pengrajin terbatas & 0,0752 & 3,271 & 0,246 \\
\hline 2 & Proses pembuatan wayang lama & 0,0818 & 3,417 & 0,279 \\
\hline 3 & Jaringan pemasaran tidak banyak & 0,0854 & 3,104 & 0,265 \\
\hline 4 & Kendala komunikasi dari pengrajin wayang & 0,0962 & 2,167 & 0,208 \\
\hline 5 & Pengrajin tidak memiliki konsep pemasaran online & 0,0872 & 2,229 & 0,194 \\
\hline \multirow[t]{4}{*}{6} & Penjualan yang tidak cukup bagus & 0,0932 & 1,875 & 0,175 \\
\hline & & 0,5189 & & 1,3679 \\
\hline & & 1,0000 & & \\
\hline & & & $x$ & $-0,2039$ \\
\hline
\end{tabular}

Kemudian hasil dari perhitungan nilai selisih eksternal (pelvang-ancaman) sebagai nilai Y adalah sebagai berikut:
Tabel 8. Perhitungan Nilai $Y$

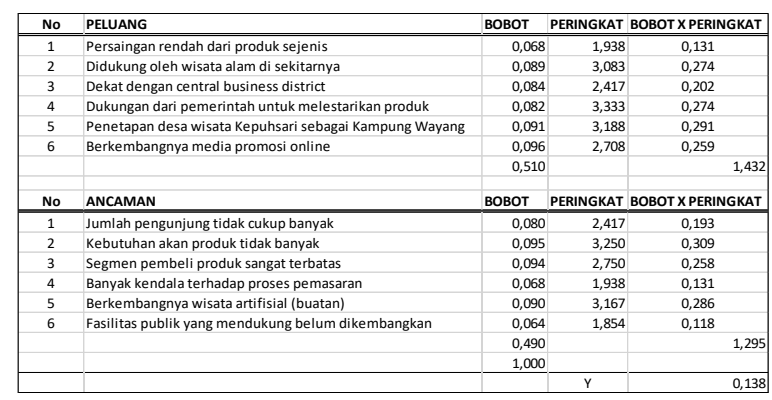

Berdasarkan tabel 7. dan 8. di atas kemudian bisa dilakukan pemetaan posisi seni kerajinan wayang Kepuhsari di kuadran SWOT adalah sebagai berikut:

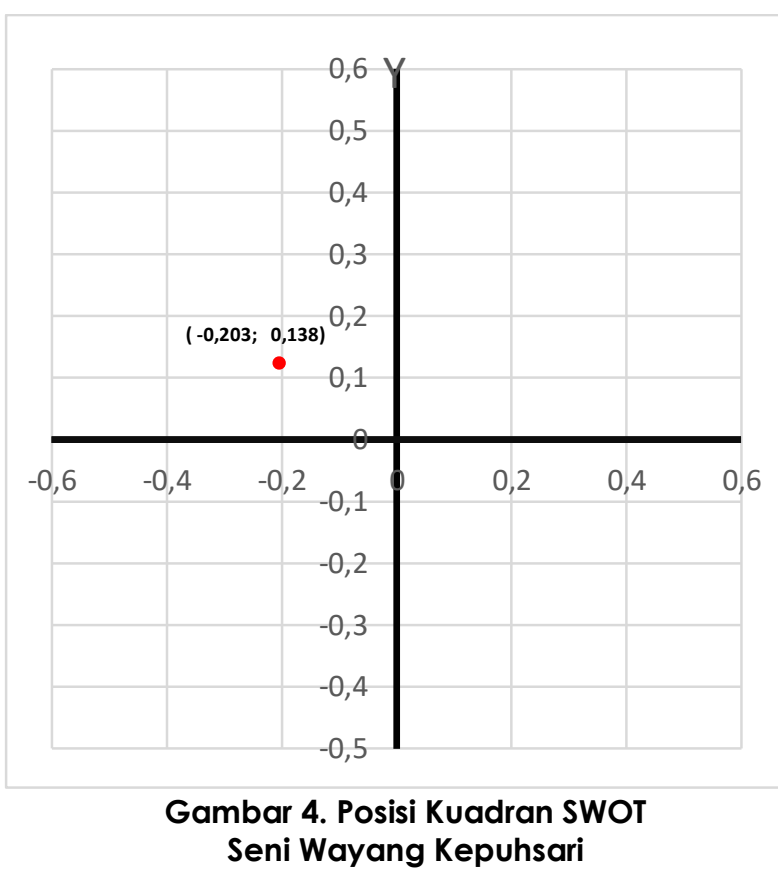

Berdasarkan analisis tersebut di atas terlihat bahwa posisi seni kerajinan wayang Kepuhsari Manyaran terletak di kuadran III dalam analisis SWOT. Kuadran III memiliki tipikal bahwa setiap bisnis sebaiknya melakukan perubahan strategi dalam pemasarannya (turn around). Ini bermakna bahwa upaya pemasaran yang selama ini dilakukan sebaiknya ditinjau ulang. Kemudian dimunculkan strategi pemasaran yang baru.

Faktor yang memiliki nilai paling besar adalah peluang, yakni 1,432. Nilai terbesar kedua adalah kelemahan, yakni 1,368. Sementara faktor ancaman memiliki nilai 1,295 dan lebih besar daripada nilai kekuatan sebesar 1,164. Selisih nilai antara masingmasing faktor tidak begitu banyak dan bahkan untuk masing-masing indikator termasuk dalam kategori lemah semua. Oleh karenanya strategi perubahan taktik pemasaran dan pengembangan lebih 
kepada memaksimalkan nilai indikator yang tertinggi dari semua yang termasuk dalam kategori lemah.

Tabel 9. Matriks Analisis SWOT

\begin{tabular}{|c|c|c|c|}
\hline & IFAS & PELUANG & ANCAMAN \\
\hline & & $\begin{array}{l}1 \text { Persaingan rendah dari produk } \\
\text { sejenis }\end{array}$ & $\begin{array}{l}1 \text { Jumlah pengunjung tidak cukup } \\
\text { banyak }\end{array}$ \\
\hline & & $\begin{array}{l}2 \text { Didukung oleh wisata alam di } \\
\text { sekitarnya }\end{array}$ & $\begin{array}{l}2 \text { Kebutuhan akan produk tidak } \\
\text { banyak }\end{array}$ \\
\hline & & $\begin{array}{l}3 \text { Dekat dengan central business } \\
\text { district }\end{array}$ & $\begin{array}{l}3 \text { Segmen pembeli produk sangat } \\
\text { terbatas }\end{array}$ \\
\hline & & $\begin{array}{l}4 \text { Dukungan dari pemerintah untuk } \\
\text { melestarikan produk }\end{array}$ & $\begin{array}{l}4 \text { Banyak kendala terhadap proses } \\
\text { pemasaran }\end{array}$ \\
\hline & & $\begin{array}{l}5 \text { Penetapan desa wisata Kepuhsari } \\
\text { sebagai Kampung Wayang }\end{array}$ & $\begin{array}{l}5 \text { Berkembangnya wisata artifisial } \\
\text { (buatan) }\end{array}$ \\
\hline & & $\begin{array}{l}6 \text { Berkembangnya media promosi } \\
\text { online }\end{array}$ & $\begin{array}{l}6 \text { Fasilitas publik yang mendukung } \\
\text { belum dikembangkan }\end{array}$ \\
\hline \multicolumn{4}{|c|}{ 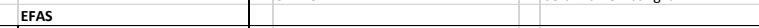 } \\
\hline & KEKUATAN & STRATEGI SO & STRATEGI ST \\
\hline & Kemampuan pengrajin mumpuni & 1. $(0.155,0.131)=($ lemah, lemah $)$ & 1. $(0.155,0.193)=($ lemah, lemah) \\
\hline & $\begin{array}{l}\text { Pengrajin telah memimiliki } \\
\text { komunitas }\end{array}$ & 2. $(0.151,0.274)=($ lemah, lemah $)$ & 2. $(0.151,0.309)=($ lemah, lemah $)$ \\
\hline & $\begin{array}{l}\text { Produknya wayang unik dan } \\
\text { spesial }\end{array}$ & 3. $(0.223,0.202)=($ lemah, lemah $)$ & 3. $(0.223,0.258)=($ lemah, lemah $)$ \\
\hline & Pasokan bahan baku lancar & 4. $(0.191,0.274)=($ lemah, lemah $)$ & 4. $(0.191,0,131)=($ lemah, lemah $)$ \\
\hline & $\begin{array}{l}\text { Produk wayang memiliki nilai jual } \\
\text { tinggi }\end{array}$ & 5. $(0.264,0.291)=($ lemah, lemah $)$ & 5. $(0.264,0,268)=($ lemah, lemah $)$ \\
\hline 6 & Fleksibilitas dalam pesanan & 6. $(0.179,0.259)=($ lemah, lemah $)$ & 6. $(0.179,0.118)=($ lemah, lemah $)$ \\
\hline & KELEMAH & & \\
\hline & Jumlah pengrajin terbatas & 1. $(0.246,0.13$ & 1. $(0.246,0.193)=($ lemah, lemah $)$ \\
\hline & Proses pembuatan wayang lama & 2. $(0.279,0.274)=($ lemah, lemah $)$ & 2. $(0.279,0.309)=$ (lemah, lemah) \\
\hline & Jaringan pemasaran tidak banyak & 3. $(0.265,0.202)=($ lemah, lemah $)$ & 3. $(0.265,0.258)=$ (lemah, lemah) \\
\hline & $\begin{array}{l}\text { Kendala komunikasi dari pengrajin } \\
\text { wayang }\end{array}$ & 4. $(0.208,0.274)=($ lemah, lemah $)$ & 4. $(0.208,0,131)=$ (lemah, lemah) \\
\hline & $\begin{array}{l}\text { Pengrajin tidak memiliki konsep } \\
\text { pemasaran online }\end{array}$ & 5. $(0.194,0.291)=(\mathrm{le}$ & 5. $(0.194,0,268)=($ lemah, If \\
\hline & Penjualan yang tidak cukup bagus & 6. $(0.175,0.259)=($ lemah, lemah $)$ & 6. $(0.175,0.118)=($ lemah, lemah $)$ \\
\hline
\end{tabular}

Berdasarkan tabel matriks SWOT di atas, maka analisa strategik untuk semua faktor (SO, ST,WO, dan WT) dirumuskan sebagai berikut:

1) Pengrajin wayang Kepuhsari telah memiliki komunitas (nilai SWOT 0,309) yang sebaiknya dapat digunakan untuk mengeliminasi ancaman berupa kebutuhan produk yang tidak banyak. Produk yang dimaksud dalam hal ini adalah wayang-wayang yang dibuat dari kulit asli dengan figur wayang sebagaimana pakem nya. Komunitas harus mampu menciptakan terobosan jenis wayang yang bisa menjadi suvernir dengan karakteristik yang sesuai dengan daya beli dari para pengunjung Kepuhsari. Langkah mengidentifikasi pola kunjungan, pola pembelian, dan daya beli pengunjung Kepuhsari juga sebaiknya dilakukan agar tercipta konektifitas (link and match) antara produk yang dihasilkan pengrajin dengan ekspektasi pengunjung.

2) Faktor kekuatan berupa produk wayang yang unik dan spesial (nilai SWOT 0,223) dapat dikembangkan dengan adanya peluang bahwa Kepuhsari relatif dekat dengan pusat perkembangan bisnis (nilai SWOT 0,202) seperti Kota Surakarta dan Daerah Istimewa Jogjakarta. Showroom yang diinisiasi bersamasama dengan anggota komunitas pengrajin yang ditempatkan di wilayah CBD menjadi hal penting untuk proses eksistensi Kampung Wayang Kepuhsari.

3) Beberapa ancaman memiliki nilai SWOT yang lebih rendah daripada kelemahan yang ada. Hal ini merupakan sesuatu yang tidak perlu untuk dikhawatirkan dengan catatan pengrajin Kepuhsari mampu memperbaiki dan meningkatkan komunikasi (nilai SWOT 0,208) di internal komunitas. Komunikasi juga penting dilakukan oleh komunitas kepada stake holder utamanya pihak pemerintah (nilai SWOT 0,274) yang sebetulnya menjadi peluang untuk bisa dimaksimalkan untuk penguatan eksistensi Kepuhsari. Di samping itu pengrajin juga perlu menjalin komunikasi dan kerjasama dengan profesional untuk pengembangan industri wayang ini (Reynaldi, 2018).

Kunci dari perubahan taktik untuk kepentingan eksistensi kampung wayang Kepuhsari Manyaran terletak pada kemampuan untuk memanfaatkan peluang yang ada. Faktor kekuatan memang memiliki nilai SWOT yang lebih rendah daripada kelemahan, namun ini juga bisa dianggap tidak membahayakan dikarenakan nilai ancaman juga nilainya lebih kecil daripada peluang yang ada. Pengrajin perlu bersinergi untuk menangkap peluang dan memaksimalkannya menjadi faktor penggerak perubahan, agar eksistensi kampung wayang Kepuhsari dapat ditingkatkan.

\section{SIMPULAN DAN SARAN \\ Simpulan}

Eksistensi kerajinan wayang Kepuhsari dapat berkontribusi pada kelangsungan salah satu warisan budaya bangsa berupa kesenian wayang. Kegiatan pengabdian ini berhasil mengungkap dan melakukan tindakan terhadap 2 hal sebagai berikut:

1. Aktivitas pemasaran yang sudah dilakukan oleh pengrajin wayang Kepuhsari yang tidak menunjukkan hasil yang memuaskan disebabkan oleh beberapa hal. Pertama, pengrajin melakukan pemasaran secara sporadis dan tidak ada komunikasi antara satu pengrajin dengan pengrajin yang lain, meskipun pengrajin wayang tersebut telah memiliki komunitas. Sporadis yang dimaksud adalah tidak berdasarkan praktik terbaik yang pernah dilakukan oleh pengrajin di tempat lain (best practice). Kedua, aktivitas pemasaran melalui media sosial dilakukan dengan seadanya kemampuan dan sumber daya yang dimiliki. Ini tidak cukup memberikan hasil yang memuaskan terhadap penjualan, walupun mampu menunjukkan eksistensi kerajinan wayang Kepuhsari. Ketiga, kerajinan wayang memiliki segmen yang tertentu dengan tingkat harga yang tertentu pula. Dengan demikian maka proses ekspansi penjualan wayang juga tidak bisa secara masif.

2. Hasil dari FGD menunjukkan bahwa posisi seni kerajinan wayang Kepuhsari berada di kuadran III dalam analisis SWOT. Ini berarti bahwa upaya pemasaran dan pengembangan yang 
dilakukan selama ini tidak cukup sesuai. Posisi kelemahan sedikit lebih dominan dibandingkan dengan kekuatan yang ada. Pada saat yang sama posisi peluang juga lebih dominan dibandingkan dengan ancamannya.

\section{Saran}

1. Pengrajin wayang Kepuhsari sebaiknya berupaya mendapatkan contoh praktik terbaik pemasaran produk wayang (best practice) dengan mempertimbangkan kesesuaian dengan potensi dan kondisi setempat. Pola pengembangan berbasis komunitas (community based development) perlu mendapatkan dukungan riil dari Pemerintah utamanya dari segi penyediaan sarana dan infrastruktur yang memadai.

2. Pengrajin wayang di Kepuhsari sebaiknya melakukan perubahan terhadap upaya pemasaran dan pengembangan terhadap produk wayangnya. Pemasaran dan pengembangan tersebut bisa dilakukan dengan mempertimbangkan faktor kelebihan, kelemahan, peluang, dan ancaman yang ada. Pengrajin bisa juga mengambil tindakan dengan berdasarkan pada praktik terbaik yang pernah dilakukan pengrajin di tempat lain (best practice).

\section{DAFTAR PUSTAKA}

APJII. 2017. Infografis Penetrasi dan Perilaku Pengguna Internet di Indonesia.Tersedia: https://apjii.or.id/survei2017/download/ICoVnNzl2afB ksDTX1e3YFGbj4gcdp

Basuki, R. (2006). Panakawan's Discourse of Power in Javanese Shadow Puppet during the New Order Regime: From Traditional Perspective to New Historicism. Kata, 8(1), 68-87.

BPS. (2018). Upah Minimum Kabupaten di Jawa Tengah.

Kusbiyanto, M. (2015). Upaya Mencegah Hilangnya Wayang Kulit Sebagai Ekspresi Budaya Warisan Budaya Bangsa. Jurnal Hukum Dan Pembangunan, $45(4)$.

Lantiva, M. C. (2019). Pasarnya Bagus, Tapi jumlah Perajin Sedikit. Retrieved from radarjogja.jawapos.com/2019/01/18/pasarnyabagus-tapi-jumlah-perajin-sedikit/

Mulawarwan dan Nur safitri. (2017). Perilaku Pengguna Media Sosial beserta Implikasinya Ditinjau dari Perspektif Psikologi Sosial Terapan. Buletin Psikologi, 25(1), 36-44.

Pujiastuti, Rahmawati, Riani, S. (2015). Pemberdayaan Industri Wayang Kulit Upaya Pengelolaan Sumber Daya Mayarakat Berbasis Kearifan Lokal.

Putro, H. T. (2015). Wayang Kulit Terancam Punah.

Santoso, A. I. (2015). Potensi UMKM Wayang Kulit di Desa Sonorejo Kecamatan Sukoharjo Kabupaten Sukoharjo. Jurnal Kewirausahaan Dan Bisnis, IX(17), 45-56. 